\title{
EVALUASI UJI KETURUNAN CENDANA (Santalum album Linn.) UMUR 8 BULAN DI KABUPATEN TIMOR TENGAH UTARA-NUSA TENGGARA TIMUR
}

Evaluation of Sandalwood (Santalum album Linn.) Progeny Test at Eight Months of Age at Timor Tengah Utara Regency-Nusa Tenggara Timur

\author{
Sumardi, Hery Kurniawan dan Misto \\ Balai Penelitian Kehutanan Kupang \\ Jl. Alfons Nisnoni (Untung Suropati) No. 7 Kupang \\ Email: sumardi_184@yahoo.com
}

\begin{abstract}
Sandalwood (Santalum album L.), a native plant of Nusa Tenggara Timur, has a very high economic value due to santalol content in the heartwood. Currently the gap between demand and production capability of sandalwood oil is high. Productivity and quality of sandalwood can be increased through a series of tree improvement activities, such as establishing a progeny test to produce genetically improved seed. Balai Penelitian Kehutanan Kupang has established a first generation progeny test of sandalwood at Timor Tengah Utara regency, Nusa Tenggara Timur province to improve the productivity of heartwood, rendemen and santalol contents. The trial was laid out in Incomplete Block Design (IBD) consisting of 65 families, 3 tree-plots, 5 replications with a spacing of $4 \times 4 \mathrm{~m}$. This study was aimed to evaluate the growth of sandalwood progeny test at eight months after planting. The result of study showed that average growth of height and diameter are $48.60 \mathrm{~cm}$ and $4.55 \mathrm{~mm}$, respectively. The estimates of family and individual heritability for height are 0.06 and 0.03 , respectively, while for diameter are 0,16 and 0,10. Genetic correlation between the height and diameter is 0.87 .
\end{abstract}

Keywords: cendana, Santalum album Linn., progeny test, heritability, genetic correlation

\begin{abstract}
ABSTRAK
Cendana (Santalum album L.) sebagai tanaman asli Nusa Tenggara Timur merupakan salah satu tanaman yang memiliki nilai ekonomi sangat tinggi karena adanya kandungan santalol pada kayu terasnya. Saat ini kesenjangan antara produksi dan permintaan minyak cendana dunia sangat tinggi. Peningkatan produksi dan kualitas cendana dapat dilakukan dengan serangkaian kegiatan pemuliaan untuk menghasilkan benih unggul secara genetik. Balai Penelitian Kehutanan Kupang telah membangun uji keturunan generasi pertama cendana di Kabupaten Timor Tengah Utara Provinsi Nusa Tenggara Timur untuk meningkatkan produksi kayu teras, rendemen dan kadar santalol. Rancangan penelitian disusun dengan rancangan Incomplete Block Design (IBD) yang terdiri dari 65 famili, 3 treeplot dan 5 blok sebagai ulangan dengan jarak tanam $4 \times 4 \mathrm{~m}$. Penelitian ini bertujuan untuk mengevaluasi tingkat pertumbuhan uji keturunan cendana umur 8 bulan setelah penanaman. Hasil penelitian menunjukkan bahwa rerata pertumbuhan tinggi dan diameter tanaman uji masing-masing sebesar 48,60 cm dan $4,55 \mathrm{~mm}$. Taksiran nilai heritabilitas famili dan individu untuk tinggi secara berurutan adalah
\end{abstract}


0,06 dan 0,03, sedangkan untuk diameter adalah 0,16 dan 0,10. Korelasi genetik tanaman uji antara sifat tinggi dan diameter sebesar 0,87 .

\section{Kata kunci: cendana, Santalum album Linn., , uji keturunan, heritabilitas, korelasi genetik}

\section{PENDAHULUAN}

Cendana (Santalum album L.) merupakan salah satu jenis tanaman asli Nusa Tenggara Timur yang memiliki nilai ekonomi sangat tinggi karena kandungan minyak atsiri pada kayu terasnya yang memiliki aroma khas (Lestari, 2010). Namun demikian populasi cendana di alam saat ini telah mengalami penurunan drastis sebagai akibat eksploitasi untuk mendapatkan keuntungan maksimal dari kayu cendana. Penurunan populasi cendana ini telah berdampak pada menurunnya jumlah produksi minyak cendana. India sebagai negara pemasok hampir $90 \%$ dari produksi minyak cendana dunia (Hussain dan Ponnuswamy, 1982), mengalami penurunan produksi sebesar $20 \%$ setiap tahunnya sejak tahun 1995 (Ananthapadmanabha, 2000). Akibat penurunan populasi dan kemampuan produksi tersebut maka terjadi kekurangan suplai minyak cendana dunia hingga mencapai 100 ton/tahun (Thomson et al., 2011).
Budidaya tanaman cendana dalam rangka peningkatan produksi dan kualitas minyak perlu terus diupayakan, disamping untuk memenuhi kebutuhan bahan baku industri juga sebagai bagian dari upaya konservasi dalam rangka menjaga kelestarian dari bahaya kepunahan. Dalam mendukung upaya budidaya tanaman ini, kegiatan pemuliaan tanaman cendana menjadi salah satu langkah yang cukup penting untuk dilakukan. Tindakan pemuliaan cendana jangka panjang untuk menghasilkan benih unggul dapat dilakukan melalui proses uji keturunan.

Propinsi Nusa Tenggara Timur merupakan salah satu wilayah sumber alami tanaman Cendana di Indonesia. Sebaran alami tanaman ini meliputi Larantuka (Flores Timur), Adonara, Solor, Lomblen, Alor, Pantar, Rote, Timor, Sumba dan Wetar (Risseeuw, 1950 dalam Surata, 2007). Dalam rangka kegiatan pemuliaan tanaman cendana, Balai Penelitian Kehutanan Kupang telah melaksanakan pengumpulan materi genetik dari beberapa populasi 
sebaran alami di Nusa Tenggara Timur. Materi genetik yang dikumpulkan telah digunakan dalam pembangunan plot uji keturunan di Stasiun Penelitian Banamlaat, Kecamatan Kefamenanu, Kabupaten Timor Tengah Utara, Provinsi Nusa Tenggara Timur. Dalam penelitian ini disajikan hasil evaluasi awal plot uji keturunan cendana tersebut untuk mendapatkan informasi variasi pertumbuhan dan beberapa parameter genetik umur 8 bulan setelah tanam. Hasil penelitian ini diharapkan dapat memberikan informasi yang bermanfaat dalam upaya membangun strategi pemuliaan cendana yang tepat ke depannya.

\section{BAHAN DAN METODE}

\section{A. Tempat dan Waktu}

Penelitian dilakukan di Stasiun Penelitian BPK Kupang di Banamlaat, Kefamenanu, Kabupaten Timor Tengah Utara, Provinsi Nusa Tenggara Timur pada bulan Juli 2013. Stasiun penelitian tersebut secara geografis terletak pada $9^{0} 30^{\prime} 8,59^{\prime \prime}$ - 9030'41,06" BT dan 124031'43" 124032'13,92" LS dengan ketinggian tempat berkisar antara $340-410 \mathrm{~m} \mathrm{dpl}$. Lokasi penelitian memiliki curah hujan rata-rata pertahun dalam kurun waktu 25 tahun terakhir (1986-2010) sebesar 1.490 mm. Kondisi topografi lokasi berdasarkan kategori Keputusan Menteri Pertanian No. $837 / \mathrm{Kpts} / \mathrm{Um} / 11 / 1980$ dan No. 683/Kpts/ Um/8/1981, termasuk kategori datar dengan kelerengan antara $0-8 \%$.

\section{B. Bahan dan Alat}

Bahan penelitian yang digunakan adalah tanaman cendana pada plot uji keturunan generasi pertama umur 8 bulan setelah tanam. Sementara peralatan yang digunakan adalah global position system (GPS), kaliper digital, penggaris $100 \mathrm{~cm}$, tally sheet, alat tulis dan komputer.

\section{Metode}

Plot uji keturunan dibangun dengan rancangan Incomplete Block Design (IBD) yang terdiri atas 65 famili, 3 treeplot dan 5 blok sebagai ulangan. Istilah famili yang dimaksud dalam penelitian ini adalah pohon induk yang digunakan sebagai sumber materi genetik. Famili yang diuji berasal dari provenan Bu'at, Netpala dan Belu. Informasi dari setiap provenan yang digunakan dalam penelitian disajikan pada Tabel 1. 
Tabel 1. Informasi sumber provenansi dan jumlah famili cendana yang digunakan pada plot uji keturunan

\begin{tabular}{|c|c|c|c|c|c|}
\hline No & Provenan & Letak Administratif & Letak geografis & $\begin{array}{l}\text { Ketinggian } \\
\text { tempat } \\
(\mathrm{m} \mathrm{dpl})\end{array}$ & $\begin{array}{l}\text { Jumlah } \\
\text { famili }\end{array}$ \\
\hline 1 & Bu'at & $\begin{array}{l}\text { Kecamatan Mollo Selatan, } \\
\text { Kabupaten Timor Tengah } \\
\text { Selatan }\end{array}$ & $\begin{array}{l}124^{0} 07^{\prime} 57^{\prime \prime} \mathrm{BT}- \\
124^{0} 19^{\prime} 38^{\prime \prime} \mathrm{BT} \\
9^{0} 47^{\prime} 07^{\prime \prime} \mathrm{LS}-9^{0} 56^{\prime} 05^{\prime \prime} \\
\mathrm{LS}\end{array}$ & $870-895$ & 22 \\
\hline 2 & Netpala & $\begin{array}{l}\text { Kecamatan Mollo Utara, } \\
\text { Kabupaten Timor Tengah } \\
\text { Utara }\end{array}$ & $\begin{array}{l}124^{0} 06^{\prime} 36^{\prime \prime} \mathrm{BT}- \\
124^{0} 18^{\prime} 48^{\prime \prime} \mathrm{BT} \\
9^{0} 39^{\prime} 16^{\prime \prime} \mathrm{LS}-9^{0} 46^{\prime} 19^{\prime \prime} \\
\text { LS }\end{array}$ & $990-1.020$ & 19 \\
\hline 3 & Belu & Kabupaten Belu & $\begin{array}{l}124^{0} 47^{\prime} 32^{\prime \prime} \mathrm{BT}- \\
125^{0} 11^{\prime} 21^{\prime \prime} \mathrm{BT} \\
8^{0} 57^{\prime} 18^{\prime \prime} \mathrm{LS}-9^{0} 233^{\prime} 40^{\prime \prime} \\
\mathrm{LS}\end{array}$ & $300-500$ & 24 \\
\hline
\end{tabular}

Variabel yang diukur pada penelitian ini meliputi adaptasi tanaman di lapangan dan keragaman sifat pertumbuhan. Adaptasi diukur melalui persen hidup tanaman yang dihitung berdasarkan data jumlah tanaman yang hidup pada setiap plot. Sifat pertumbuhan tanaman meliputi sifat tinggi dan diameter tanaman. Tinggi tanaman diukur mulai dari permukaan tanah hingga ujung tanaman, sedangkan diameter diukur pada ketinggian $5 \mathrm{~cm}$ di atas permukaan tanah. Pengukuran diameter pada ketinggian $5 \mathrm{~cm}$ di atas permukaan tanah dilakukan mengingat sebagian besar tinggi tanaman uji belum mencapai diameter setinggi dada $(\mathrm{dbh} /$ diameter at breast height). Dengan demikian untuk menjaga konsistensi letak pengukuran diameter maka dipilih letak tertentu dari diameter batang.

\section{Analisis Data}

Analisa data untuk adaptasi tanaman diukur berdasarkan data persen hidup tanaman di lapangan dalam masing-masing plot dengan menggunakan model linier sebagai berikut :

$$
Y_{i j k l}=\mu+B_{i}+P_{j}+F(P)_{k j}+E_{i j k l} \ldots \ldots \ldots \ldots \ldots l
$$

dimana:

$Y_{i j k l} \quad$ : pengamatan pada plot ke- $l$ dari famili ke- $k$ dan provenan ke-j, dalam blok ke- $i$;

$\mu \quad$ : rerata umum hasil pengukuran;

$B_{i} \quad$ : pengaruh blok ke- $i$;

$P_{j} \quad$ : pengaruh provenan ke-j;

$F(P)_{k j}$ : pengaruh famili ke- $k$ yang bersarang pada provenan ke-j;

$E_{i j k l} \quad$ : galat

Analisa data untuk sifat pertumbuhan tanaman (tinggi dan diameter) dilakukan 
dengan menggunakan data individual tanaman dan dihitung menggunakan model rancangan Randomized Complete Block Design. Pemilihan model linier tersebut berdasarkan pertimbangan kondisi topografi lokasi plot penelitian yang relatif datar dan berada dalam satu hamparan, sehingga homogenitas tapak di dalam masing-masing blok relatif tinggi, secara simbolis analisa data disajikan dengan model linier sebagai berikut :

$Y_{i j k l}=\mu+B_{i}+P_{j}+F(P)_{k j}+B * F_{i k}+E_{i j k l \ldots} 2$

dimana:

$Y_{i j k l} \quad$ : pengamatan pada individu pohon ke- $l$ dari famili ke- $k$ dan provenan ke-j, dalam blok ke- $i$;

$\mu \quad$ : rerata umum hasil pengukuran;

$B_{i} \quad$ : pengaruh blok ke- $i$;

$P_{j} \quad$ : pengaruh provenan ke-j;

$F(P)_{k j}$ : pengaruh famili ke- $k$ yang bersarang pada provenan ke-j;

$B^{*} F_{i k}$ : pengaruh interaksi blok ke- $i$ dan famili ke- $k$;

$E_{i j k l} \quad$ : galat

Pengamatan terhadap parameter genetik dilakukan dengan menghitung besarnya nilai heritabilitas dan korelasi genetik antar sifat. Nilai heritabilitas individu $\left(h^{2}\right)$ dan heritabilitas famili $\left(h^{2}\right)$ dihitung menggunakan rumus taksiran heritabilitas (Zobel \& Talbert, 1984):

$$
h^{2}{ }_{i}=\frac{4 \sigma_{f}^{2}}{\sigma_{f}^{2}+\sigma_{f b}^{2}+\sigma^{2}{ }_{\theta}}
$$

$$
h^{2}{ }_{f}=\frac{\sigma_{f}^{2}}{\sigma_{f}^{2}+\sigma^{2}{ }_{f b} / b+\sigma^{2}{ }_{\theta} / n b}
$$

dimana:

$\sigma_{f}^{2} \quad$ : komponen varians famili

$\sigma_{f b}^{2} \quad$ : komponen varians interaksi famili dengan blok

$\sigma_{e}^{2} \quad:$ komponen varians error

$n \quad$ : rerata harmonik jumlah pohon per plot

$b \quad$ : rerata harmonik jumlah blok

Korelasi genetik antar sifat pertumbuhan dihitung dengan menggunakan persamaan berikut (Zobel \& Talbert, 1984):

$r_{G}=\frac{\sigma_{f(x y)}}{\sqrt{\sigma_{f(x)}^{2} \cdot \sigma_{f(y)}^{2}}}$ 5

dimana:

$r_{G} \quad:$ korelasi genetik;

$\sigma_{f(x y)}$ : komponen kovarians antara sifat $(x)$ dan sifat $(y)$;

$\sigma_{f(x)}^{2} \quad$ : komponen varians untuk sifat $(x)$; $\sigma_{f(y)}^{2}$ : komponen varians untuk sifat (y).

\section{HASIL DAN PEMBAHASAN}

\section{A. Adaptasi Tanaman di Lapangan}

Kemampuan beradaptasi suatu tanaman salah satunya ditunjukkan dengan kemampuan suatu tanaman untuk bertahan hidup pada suatu kondisi lingkungan tertentu. Persen hidup tanaman pada plot uji keturunan generasi pertama (F-1) cendana 
di Kabupaten Timor Tengah Utara Provinsi Nusa Tenggara Timur bervariasi antara $33,33 \%$ hingga $100 \%$ per plot (famili per blok) dengan rata-rata dari seluruh famili sebesar 78,94\%. Persen hidup tanaman jika dibedakan berdasarkan provenan maka persen hidup provenan Bu'at, Belu dan Netpala masing-masing sebesar $85,45 \%, 76,11 \%$, dan $75,28 \%$. Analisis varians terhadap persen hidup tanaman uji keturunan cendana sampai dengan umur 8 bulan setelah tanam disajikan pada Tabel 2 .

Tabel 2. Analisis varians persen hidup tanaman pada plot uji keturunan cendana umur 8 bulan

\begin{tabular}{lrr}
\hline Sumber variasi & $\begin{array}{l}\text { Derajat } \\
\text { bebas }\end{array}$ & Kuadrat tengah \\
\hline Blok & 4 & $522,072^{\text {ns }}$ \\
Provenan & 2 & $2.378,602^{\text {ns }}$ \\
Famili(provenan) & 62 & $383,608^{\text {ns }}$ \\
Galat & 223 & 398,368 \\
\hline
\end{tabular}

Keterangan :

ns : tidak berbeda nyata pada taraf uji 5\%

Meskipun persen hidup tanaman pada setiap plot berkisar antara $33,33 \%$ hingga $100 \%$, hasil analisis varians yang disajikan pada Tabel 2 menunjukkan tidak ada perbedaan secara signifikan antar provenan maupun antar famili yang diuji. Dengan demikian famili-famili yang berasal dari ketiga provenan yakni Bu'at, Netpala dan Belu relatif memiliki kemampuan yang sama dalam beradaptasi terhadap kondisi tapak pada plot uji keturunan cendana. Hal tersebut kemungkinan disebabkan oleh karena kondisi klimatologis dan geografis ketiga provenan yang masih termasuk dalam kisaran persyaratan tumbuh cendana. Cendana secara klimatologis mampu tumbuh pada kondisi curah hujan antara $500-3.000 \mathrm{~mm}$ pertahun, sementara data curah hujan di wilayah Bu'at, Belu dan Netpala dalam kurun waktu 25 tahun terakhir (1986-2010) masing-masing sebesar $1.673 \mathrm{~mm}, 1.844 \mathrm{~mm}$ dan $1921 \mathrm{~mm}$ pertahun (Badan Meteorologi, Klimatologi dan Geofisika Kupang, 2011). Kondisi geografis ketiga provenan berdasarkan ketinggian tempat juga termasuk dalam kisaran persyaratan tumbuh cendana yakni pada ketinggian tempat hingga $1.800 \mathrm{~m}$ dpl meskipun cendana di NTT banyak dijumpai pada ketinggian 300-1300 m dpl (Hamilton \& Cornard, 1990). Ketinggian tempat provenan Bu'at adalah berkisar 870-895 mdpl, Netpala 990-1020 m dpl dan Belu 300-500 m dpl. Lokasi penelitian juga berada dalam kisaran persyaratan tempat tumbuh cendana yakni berada pada ketinggian $410 \mathrm{~m}$ dpl dan memiliki curah hujan $1.490 \mathrm{~mm}$ pertahun. Hal tersebut kemungkinan yang mempengaruhi 
tingginya daya adaptasi tanaman uji dari semua provenan di lokasi penelitian yaitu lebih dari $75 \%$. Sebagai perbandingan, secara umum data keberhasilan penanaman cendana di lapangan hanya mencapai 20 $40 \%$ di lapangan (Surata, 2007).

\section{B. Keragaman Sifat Pertumbuhan}

Sifat pertumbuhan yang diukur pada penelitian ini adalah sifat tinggi dan diameter tanaman. Rerata pertumbuhan tinggi tanaman uji pada masing-masing famili berkisar antara $20,00 \mathrm{~cm}$ sampai dengan $146,00 \mathrm{~cm}$. Sedangkan rerata pertumbuhan diameternya berkisar antara 2,03 mm sampai dengan $13,47 \mathrm{~mm}$. Rerata pertumbuhan tinggi jika didasarkan pada provenan masing-masing yaitu sebesar $51,08 \mathrm{~cm}$ (Bu'at), 48,19 cm (Netpala) dan 45,80 cm (Belu). Sedangkan untuk diameter sebesar 4,77 mm (Bu'at), 4,50 mm (Netpala), dan 4,32 mm (Belu). Provenan Bu'at menunjukkan pertumbuhan tinggi dan diameter yang paling baik, diikuti Netpala dan Belu. Ditinjau dari kondisi iklim, provenan $\mathrm{Bu}$ 'at memiliki kemiripan yang paling dekat dengan kondisi iklim di lokasi penanaman. Bu'at memiliki rata-rata curah hujan per tahun sebesar $1.673 \mathrm{~mm}$, paling mirip dengan kondisi di lokasi penelitian $(1.490 \mathrm{~mm})$ dibanding Netpala $(1.921 \mathrm{~mm})$ dan Belu (1.844 mm) (Badan Meteorologi, Klimatologi dan Geofisika Kupang, 2011). Dengan demikian kemungkinan besar tanaman cendana dari provenan Bu'at memiliki kemampuan untuk tumbuh lebih baik dibanding dua provenan lainnya. Berdasarkan kondisi curah hujan, provenan $\mathrm{Bu}$ 'at merupakan sebaran alami cendana yang memiliki curah hujan paling optimal untuk pertumbuhan cendana dibandingkan dengan 2 provenan lainnya. Cendana akan tumbuh optimal pada daerah dengan curah hujan 600 - 1600 mm (Ramya, 2010).

Analisis varians terhadap sifat pertumbuhan tinggi dan diameter tanaman yang diuji disajikan pada Tabel 3.

Tabel 3. Analisis varians tinggi dan diameter tanaman pada plot uji keturunan umur 8 bulan

\begin{tabular}{|c|c|c|c|}
\hline Sumber variasi & Derajat bebas & $\begin{array}{l}\text { Kuadrat tengah } \\
\text { tinggi }\end{array}$ & $\begin{array}{l}\text { Kuadrat tengah } \\
\text { diameter }\end{array}$ \\
\hline Blok & 4 & $3622,790 * *$ & $9,922 * *$ \\
\hline Provenan & 2 & $1745,536^{* *}$ & $11,560 * *$ \\
\hline Famili(provenan) & 62 & $691,399 * *$ & $4,078 * *$ \\
\hline Blok*famili & 217 & $599,383 * *$ & $3,175^{* *}$ \\
\hline Galat & 445 & 247,665 & 1,532 \\
\hline
\end{tabular}

Keterangan : ** : berbeda nyata pada taraf uji $1 \%$ 
Berbeda dengan hasil analisis varians terhadap adaptasi tanaman (Tabel 2), sifat pertumbuhan tanaman memperlihatkan adanya perbedaan secara signifikan baik antar provenan maupun antar famili yang diuji. Provenan dengan persen hidup yang lebih tinggi (Bu'at) cenderung menunjukkan pertumbuhan tinggi dan diameter tanaman yang lebih baik. Namun demikian perlu dicatat disini bahwa perbedaan secara signifikan pada sifat tinggi dan diameter ini didasarkan pada data pengukuran tanaman yang masih relatif muda ( 8 bulan), sehingga sangat berpotensi untuk berubah pada umur yang lebih tua. Perbedaan secara signifikan antar famili pada pertumbuhan tinggi dan diameter juga terjadi pada tanaman uji keturunan cendana umur 6 bulan di Gunungkidul (Yuliah dan Haryjanto, 2005).

Perbedaan secara signifikan di antara famili memberikan indikasi bahwa secara umum famili yang diuji pada plot uji keturunan memiliki keragaman genetik yang tinggi untuk sifat tinggi dan diameter tanaman. Hasil penelitian ini sejalan dengan hasil penelitian keragaman genetik cendana menggunakan penanda DNA yang dilakukan pada kebun konservasi ex situ cendana di Gunungkidul. Keragaman genetik pada kebun konservasi ex situ di Gunungkidul cukup tinggi $\left(\mathrm{H}_{\mathrm{E}}=0,391\right)$ pada 17 populasi yang diteliti dengan menggunakan penanda RAPD (Random Amplified Polymorphic DNA) (Rimbawanto, et al., 2006). Dari 17 Populasi yang diteliti menggunakan penanda RAPD tersebut salah satunya adalah populasi Bu'at yang juga digunakan sebagai materi untuk pembangunan uji keturunan pada penelitian ini. Hasil yang hampir sama juga diperoleh oleh Haryjanto (2009) yang melaporkan bahwa keragaman genetik cendana masih cukup tinggi $\left(\mathrm{H}_{\mathrm{E}}=0,366\right)$ pada 6 populasi pada kebun konservasi ex situ cendana di Gunungkidul, yang diteliti dengan menggunakan penanda isozim. Salah satu populasi yang digunakan dalam penelitian dengan menggunakan penanda isozim tersebut adalah populasi Belu, yang juga digunakan sebagai materi untuk pembangunan uji keturunan pada penelitian ini. Keragaman genetik di dalam populasi untuk tanaman berkayu tahunan di daerah tropis maupun jenis konifer pada umumnya lebih rendah, yaitu sebesar 0,211 dan 0,207 (Hamrick, 1989 dalam Rimbawanto, et al. (2006).

Hasil penelitian Rimbawanto, et al. (2006) menggunakan penanda DNA dan 
Haryjanto (2009) menggunakan penanda isozim menunjukkan keragaman genetik cendana masih relatif tinggi antar famili. Hasil yang sama pada analisis varians sifat pertumbuhan tinggi dan diameter tanaman uji keturunan juga menunjukkan keragaman genetik yang relatif tinggi antar famili. Nilai keragaman genetik cendana pada penelitian Haryjanto (2009) yang menggunakan materi hasil eksplorasi 2005 lebih rendah dibanding dengan hasil penelitian Rimbawanto, et al. (2006) yang menggunakan materi hasil eksplorasi 2002. Nilai keragaman genetik pada kedua penelitian tersebut mengindikasikan terjadinya penurunan keragaman genetik sebagai akibat penurunan populasi cendana di alam. Data inventarisasi tegakan cendana oleh Dinas Kehutanan NTT tahun 1987-1988 dan 1997-1998 menunjukkan adanya penurunan populasi sebesar $85 \%$ dalam kurun waktu 10 tahun (William, 2001), hingga saat ini belum ada data inventarisasi tegakan cendana terbaru. Dengan demikian, keragaman genetik pada tanaman uji keturunan cendana ini jika dianalisis menggunakan penanda DNA atau isozim kemungkinan akan menunjukkan nilai yang lebih rendah dibanding kedua penelitian sebelumya. Hal tersebut karena materi yang digunakan untuk pembangunan uji keturunan merupakan hasil eksplorasi 2011 dengan populasi cendana di alam lebih sedikit dibanding 2002 dan 2005 . Untuk itu ke depan, analisis keragaman genetik terhadap tanaman uji keturunan menggunakan penanda DNA atau isozim perlu dilakukan untuk menentukan strategi breeding cendana lebih lanjut. Jika ternyata nilai keragaman genetiknya terbukti lebih rendah maka perlu dilakukan tindakan infusi dari tegakan konservasi di Gunungkidul untuk menambah variasi genetik pada tanaman uji keturunan.

\section{Nilai Heritabilitas}

Untuk mengetahui proporsi faktor genetik yang diturunkan dari induk kepada keturunannya, maka dilakukan penaksiran nilai heritabilitas (Zobel \& Talbert, 1984). Nilai heritabilitas individu $\left(h^{2}\right)$ dan famili $\left(h^{2}\right)$ untuk sifat tinggi dan diameter pada tanaman uji keturunan cendana sampai dengan umur 8 bulan setelah tanam disajikan pada Tabel 4

Tabel 4. Heritabilitas individu dan famili pada plot uji keturunan cendana umur 8 bulan

\begin{tabular}{lll}
\hline Sifat & $\begin{array}{l}\text { Heritabilitas } \\
\text { individu } \\
\left(h^{2}\right)\end{array}$ & $\begin{array}{l}\text { Heritabilitas } \\
\text { famili } \\
\left(h^{2}\right)\end{array}$ \\
\hline Tinggi & 0,03 & 0,06 \\
Diameter & 0,10 & 0,16 \\
\hline
\end{tabular}


Nilai heritabilitas untuk sifat diameter secara umum menunjukkan nilai yang lebih tinggi dibandingkan untuk sifat tinggi. Heritabilitas individu tanaman uji berdasarkan klasifikasi Cotterill \& Dean (1990) untuk sifat tinggi termasuk kategori rendah yaitu sebesar 0,03 dan untuk sifat diameter termasuk kategori sedang yaitu sebesar 0,10. Sedangkan untuk nilai heritabilitas familinya untuk kedua sifat termasuk kategori rendah, yaitu sebesar 0,06 (tinggi) dan 0,16 (diameter). Rendahnya nilai heritabilitas pada tanaman cendana umur 8 tahun kemungkinan disebabkan oleh karena umur tanaman yang masih relatif muda. Sebagaimana pada pengamatan terhadap keragaman genetik, nilai heritabilitas pada plot uji keturunan cendana ini juga berpotensi berubah pada umur yang lebih tua. Tren atau pola perubahan nilai heritabilitas pada beberapa umur tanaman tersebut perlu diketahui untuk melihat konsistensinya yang sangat bermanfaat dalam mendukung efektifitas strategi pemuliaan ke depannya, khususnya dalam efisiensi pelaksanaan seleksi. Hal tersebut seperti terjadi pada tanaman uji keturunan A. mangium dari populasi Queensland yang menunjukkan adanya nilai heritabilitas yang berbeda antara umur 16 bulan dan 32 bulan untuk sifat tinggi dan diameter tanaman (Nirsatmanto, 2005).

\section{Korelasi Genetik}

Korelasi genetik digunakan untuk mengetahui hubungan genetik antara sifat tinggi dan diameter pada tanaman uji keturunan. Korelasi genetik sangat penting untuk memprediksi pengaruh dan efektifitas seleksi yang dilakukan terhadap suatu sifat (Gaspar, et al., 2008). Korelasi genetik antara sifat tinggi dan diameter pada uji keturunan cendana adalah sebesar 0,87. Nilai korelasi tersebut cukup besar dan positif, yang berarti setiap peningkatan diameter yang disebabkan oleh seleksi diameter akan diikuti oleh peningkatan tinggi tanaman uji. Dengan peningkatan diameter dan tinggi tanaman maka secara otomatis juga meningkatkan volume kayu.

Peningkatan volume kayu cendana diharapkan akan diikuti oleh peningkatan volume kayu teras sebagai produk akhir dari cendana. Penelitian yang dilakukan di Miomafo Timur Kabupaten Timor Tengah Utara Provinsi Nusa Tenggara Timur menunjukkan bahwa produksi kayu teras cendana dipengaruhi oleh diameter batang sebesar 79,3\% dan tinggi pohon 
sebesar 64,5\% (Susila, 1993). Dengan demikian apabila nilai korelasi genetik tersebut konsisten sampai waktu dilakukan tindakan seleksi, maka seleksi akan lebih efisien dengan menggunakan satu sifat saja. Tindakan seleksi pada tanaman cendana secara operasional akan lebih mudah dilakukan menggunakan sifat diameter dan secara otomatis akan memperbaiki sifat tinggi dibanding melakukan seleksi sifat tinggi. Namun demikian perlu dicatat disini bahwa pengamatan terhadap diameter pada penelitian ini masih dilakukan pada ketinggain $5 \mathrm{~cm}$ di atas permukaan tanah sehingga belum sepenuhnya mencerminkan nilai operasional volume kayu yang akan dihasilkan. Untuk itu ke depan pengukuran dan evaluasi plot uji keturunan cendana ini perlu dilakukan secara periodik untuk melihat pola pertumbuhan dan perubahan parameter genetik sehingga lebih menceminkan produktivitas tegakan secara operasional.

\section{KESIMPULAN}

Evaluasi uji keturunan cendana pada umur 8 bulan menunjukkan adanya pengaruh secara signifikan pada provenan dan famili yang diuji untuk sifat tinggi dan diameter tanaman, tetapi tidak ada perbedaan yang signifikan terhadap persen hidup tanaman. Famili-famili dari provenan Buat dan Netpala menunjukkan pertumbuhan tinggi dan diameter lebih baik dibanding dengan famili-famili asal provenan Belu. Nilai heritabilitas individu dalam kategori rendah untuk sifat tinggi $(0,03)$ dan sedang untuk sifat diameter $(0,10)$. Sedangkan nilai heritabilitas famili termasuk dalam kategori rendah untuk sifat tinggi $(0,06)$ dan diameter $(0,16)$. Korelasi genetik antara sifat tinggi dan diameter cukup kuat, yaitu sebesar 0,87 .

\section{UCAPAN TERIMA KASIH}

Kami menyampaikan terima kasih koordinator Rencana Penelitian Integratif Bioteknologi Hutan dan Pemuliaan Tanaman Hutan, Teknisi dan Pembantu Teknisi di Stasiun Penelitian BPK Kupang di Banamlaat : Martinus Lalus, Kornelis Missa, Kristoforus dan semua pihak yang tidak mungkin kami sebutkan satu persatu yang telah membantu penelitian ini. 


\section{DAFTAR PUSTAKA}

Ananthapadmanabha, H.S. 2000. Sandal wood and its marketing trend. My forest 36:154-160.

Badan Meteorologi, Klimatologi dan Geofisika Kupang. 2011. Data curah hujan bulanan Provinsi Nusa Tenggara Timur. Badan Meteorologi, Klimatologi dan Geofisika Kupang, $114 \mathrm{p}$.

Cotteril, P.P. and C.A. Dean. 1990. Successful Tree Breeding with Index Selection. CSIRO Division of Forestry and forest Product, Australia, 80p.

Gaspar, M.J., J.L. Louzada, A. Aguiar, and M.H. Almeida. 2008. Genetic correlations between wood quality traits of Pinus pinaster Ait. Annals of Forest Science 65:1-6.

Hamilton, L. and C.E. Conrad (eds.). 1990. Proceedings of the Symposium on Sandalwood in the Pacific, 9-11 April 1990, Honolulu, Hawaii. General Technical Report PSW-122, CA: Pacific Southwest Research Station, Forest Service, U.S. Department of Agriculture: $84 \mathrm{p}$.

Haryjanto, L. 2009. Keragaman Genetik Cendana (Santalum album Linn) di Kebun Konservasi Ex Situ Watusipat, Gunungkidul, Dengan Penanda Isozim. Jurnal Pemuliaan Tanaman Hutan 3(3):127-138.

Hussain, A.M. and P.K. Ponnuswamy. 1982. An innovation in the vegetative propagation of sandal. Indian Journal Forestry 5:1-7.

Kementerian Pertanian. 1980. Keputusan Menteri Pertanian No. 837/Kpts/ Um/11/1980 tentang kriteria dan tata cara penetapan hutan lindung dan hutan produksi. Jakarta: Kementerian Pertanian.

Kementerian Pertanian. 1981. Keputusan Menteri Pertanian No. 683/Kpts/ $\mathrm{Um} / 8 / 1981$, tentang kriteria dan tata cara penetapan hutan lindung dan hutan produksi. Jakarta:
Kementerian Pertanian.

Lestari, F. 2010. Karakteristik Pembungaan Tiga Provenan Dan Empat Ras Lahan Cendana. Jurnal Pemuliaan Tanaman Hutan 7(2):59-65.

Nirsatmanto, A. 2005. Study on Statistical Genetic Analysis and Application to The Breeding in Acacia mangium. Doctoral Thesis. Kyusu University, $101 p$.

Ramya, R. 2010. Physiological And genetic Diversity Studies On Regeneration Of Santalum album L. Doctoral Thesis. Kerala Forest Research Institute Peechi, 151p.

Rimbawanto, A., AYBPC Widyatmoko dan P. Sulistyowati. 2006. Distribusi Keragaman Genetik Populasi Santalum album L berdasarkan Penanda RAPD. Jurnal Penelitian Hutan Tanaman 3(3):175-181.

Surata, I.K. 2007. Teknik Pengembangan Budidaya Cendana (Santalum album L.) di lahan Masyarakat. Dalam : Siran, S.A., Butar-Butar, T., A.N. Gintings, C. Anwar, H. Suhaendi, Pratiwi., D. Wahyono, I.K. Surata (eds.). Prosiding Gelar Teknologi Cendana. Pusat Penelitian dan Pengembangan Konservasi dan Sumber daya Alam, 1-17.

Susila, I.W.W. 1993. Hubungan kandungan Kayu Teras Cendana dengan Beberapa Parameter di Miomafo Yimur, kabupaten Timor Tengah Utara. Laporan Teknis 6:31.

Thomson, L.A.J., J. Doran, D. Harbaugh, and M.D. Merlin. 2011. Farm and Forestry Production and Marketing Profile for Sandalwood (Santalum species). In: Elevitch, C.R. (ed.). Specialty Crops for Pacific Island Agroforestry. Permanent Agriculture Resources (PAR), Holualoa, Hawai 'i. http://agroforestry.net/scps, 1-29

William, A.M. 2001. Haumeni, Not Many: Renewed Plunder and Mismanagement in the Timorese Sandalwood Industry. Resource 
Management in Asia-Pacific Program. Cambridge University Press - Modern Asian Studies 39(2):285-320.

Yuliah dan L. Haryjanto. 2005. Uji Keturunan Semai Cendana Umur Enam Bulan di Persemaian. Wana Benih 6(1):108-114.

Zobel, B. and J. Talbert. 1984. Applied forest tree improvement. John Willey \& Sons, New York, 521p. 